Readers who found these articles interesting may also like to read these papers that can be found in recent issues of our sister publications, Seminars in Thoracic and Cardiovascular Surgery and Operative Techniques in Thoracic and Cardiovascular Surgery.

\title{
THORACIC
}

New

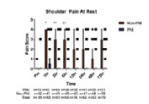

ORIGINAL SUBMISSION: A randomized study comparing the incidence of postoperative pain after phrenic nerve infiltration vs non-phrenic nerve infiltration during thoracotomy. B Krishnamoorthy. Semin Thoracic Surg 2018: In press

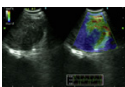

ORIGINAL SUBMISSION: Localization of the metastatic site within a lymph node using endobronchial elastography. Ichiro Yoshino. Semin Thoracic Surg 2018: In press

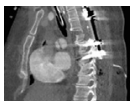

CASE REPORT: Atypical Right Pulmonary Artery Dissection Complicating Severe Blunt Chest

Trauma. Julie Felten. Semin Thoracic Surg 2018: In press

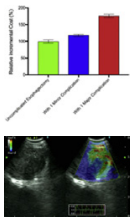

ORIGINAL MANUSCRIPT: Relative Incremental Cost of Postoperative Complications of Esophagectomy:

Michael Lanuti. Semin Thoracic Surg 2018: In press

BRIEF RESEARCH REPORT: Localization of the metastatic site within a lymph node using endobronchial elastography. Yuki Shiina. Semin Thoracic Surg 2018: In press

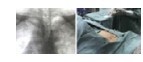

ORIGINAL SUBMISSION: Outcome of Percutaneous Radiofrequency Thoracic Sympathectomy for Palmar Hyperhidrosis. Daniele Cataneo. Semin Thoracic Surg 2018: In press

\section{Lung Cancer}
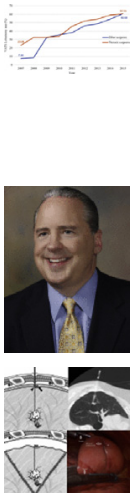

ORIGINAL SUBMISSION: Trends and Outcomes of Thoracoscopic Lobectomy or Segmentectomy: A National Surgical Quality Improvement Project Analysis. Ikenna Okereke. Semin Thoracic Surg 2018: in Press

Editorial Commentary: \#vatslobectomy: Daniel Miller: Semin Thoracic Surg 2018: in Press

ORIGINAL SUBMISSION: Microcoil-Guided Video Assisted Thoracoscopic Excision of Nodules suspicious for Metastasis in Patients with ExtraThoracic Malignancies. Omamah Almousa. Semin Thoracic Surg 2018: in Press

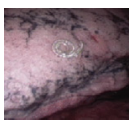

Editorial Commentary: Will the Real Slim Shady Please Stand Up? DuyKhanh P. Ceppa. Semin Thoracic Surg 2018: in Press

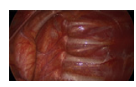

Editorial Commentary: Percutaneous Radiofrequency Ablation for Hyperhidrosis: Ready for Primetime? Rafael Andrade. Semin Thoracic Surg 2018: In press

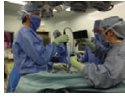

SURGICALTECHNIQUE: Mediastinal Parathyroidectomy Using a Cervical Approach Under a

Pneumomediastinum. Mitsuhiro Tsuboi. Semin Thoracic Surg 2018: Volume 30, Issue 4

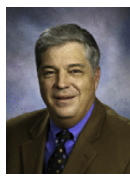

Editorial Commentary: What is the Best Surgical Approach to the Superior Mediastinum? Stephen Hazelrigg. Semin Thoracic Surg 2018: Volume 30, Issue 4

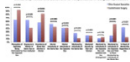

ORIGINAL MANUSCRIPT: Social Media as a Means of Networking and Mentorship: Role for Women in Cardiothoracic Surgery. Jessica Luc. Semin Thoracic Surg 2018: Volume 30, Issue 4

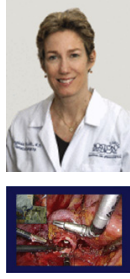

Editorial Commentary: The Good, the Bad and the Socially Challenged. Virginia R. Litle. Semin Thoracic Surg 2018: Volume 30, Issue 4

SURGICAL TECHNIQUE: Clinical Experience of Thoracoscopic Sleeve Lobectomy Using a Novel Needle Holder. Tatsuo Nakagawa. Semin Thoracic Surg 2018: In press

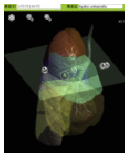

ORIGINAL SUBMISSION: Three-dimensional Navigation for Thoracoscopic Sublobar Resection Using a Novel Wireless Marking System. Yojiro Yutaka. Semin Thoracic Surg 2018: 230-237

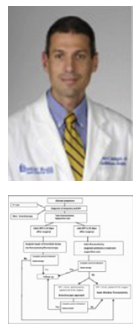

Editorial Commentary: Searching for the Holy Grail and Small Pulmonary Nodules. Chadrick E. Denlinger. Semin Thoracic Surg 2018: 238-239

ORIGINAL SUBMISSION: Broncho-Pleural Fistula after Pneumonectomy: Risk Factors and Management, Focusing on Open Window Thoracostomy. Antonio Mazzella. Semin Thoracic Surg 2018: 104-113

Editorial Commentary: Management of PostPneumonectomy Bronchopleural Fistula: a Roadmap for Rescue. Virginia R. Litle. Semin Thoracic Surg 2018: 114115 


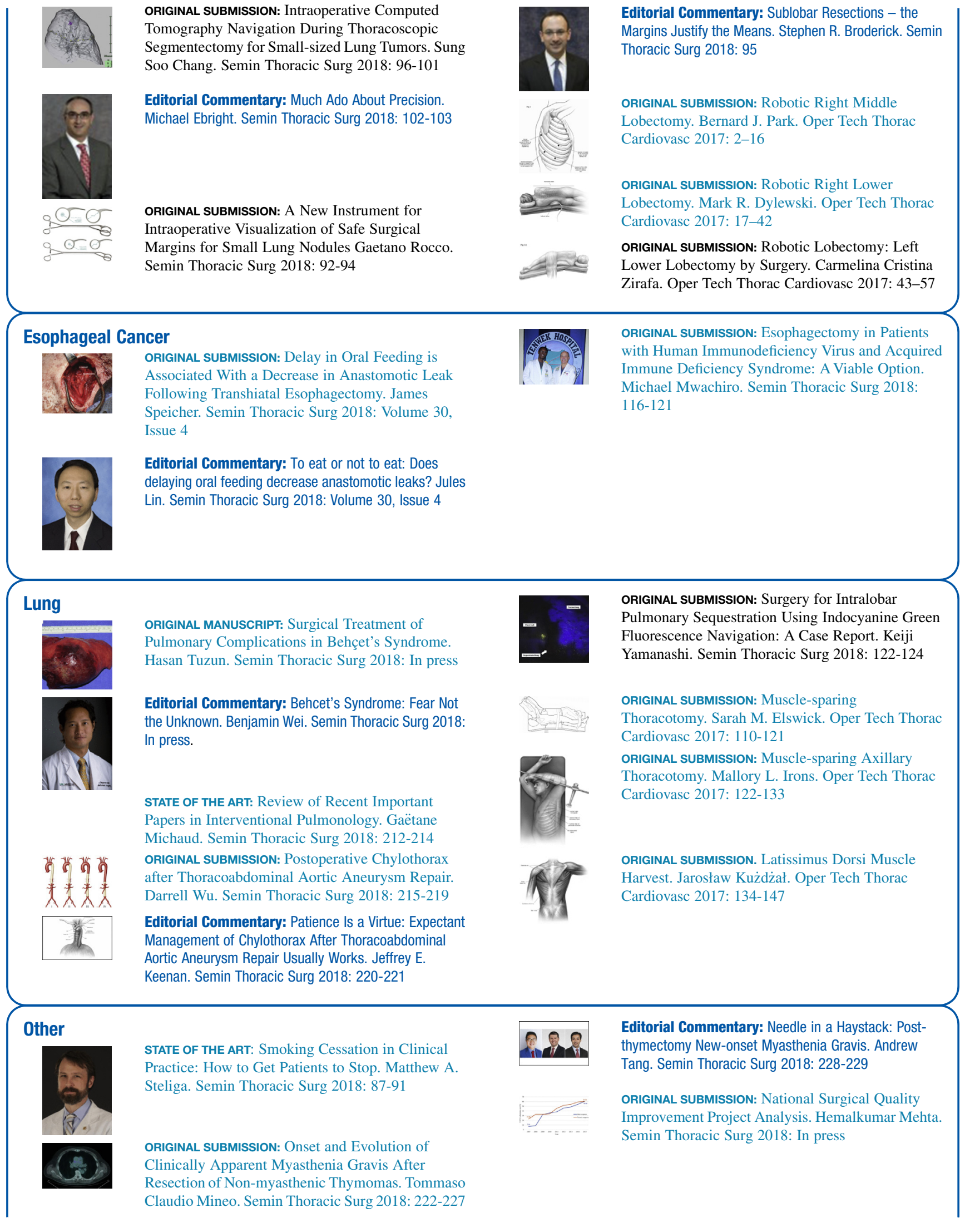

ORIGINAL SUBMISSION: Intraoperative Computed During Thoracoscopic

INAL SUBMISSION: A New Instrument for Margins for Small Lung Nodules Gaetano Rocco. Semin Thoracic Surg 2018: 92-94 Lobectomy. Bernard J. Park. Oper Tech Thorac Lobectomy. Mark R. Dylewski. Oper Tech Thorac asc 2017: 17-42

Lower Lobectomy by Surgery. Carmelina Cristina Zirafa. Oper Tech Thorac Cardiovasc 2017: 43-57

Esophagectony in Patients . Michael Mwachiro. Semin Thoracic Surg 2018: 116-12 Yamanashi. Semin Thoracic Surg 2018: 122-124

ORIGINAL SUBMISSION: Muscle-sparing Thoracotomy. Sarah M. Elswick. Oper Tech Thorac Cardiovasc 2017: 110-12 Thoracotomy. Mallory L. Irons. Oper Tech Thorac Cardiovasc 2017: 122-133

ORIGINAL SUBMISSION. Latissimus Dorsi Muscle Harvest. Jarosław Kużdżał. Oper Tech Thorac Cardiovasc 2017: 134-147 
ORIGINAL SUBMISSION: A Randomized Controlled Trial of Continuous Subpleural Bupivacaine After Thoracoscopic Surgery. Charles D. Ghee. Semin Thoracic Surg 2018: 240-249

\section{ADULT}

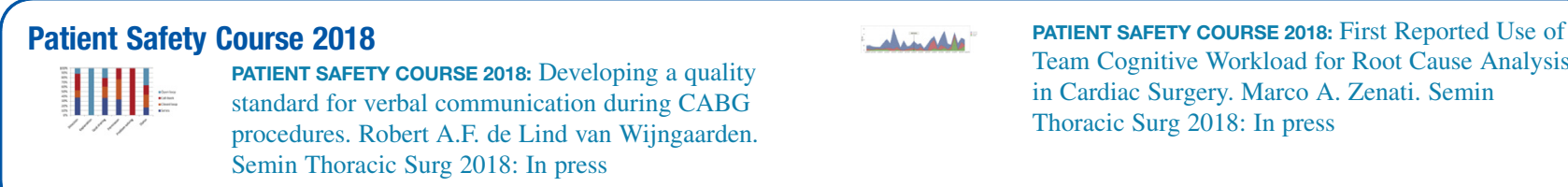

New

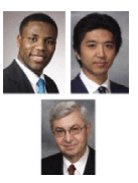

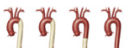

美美齐
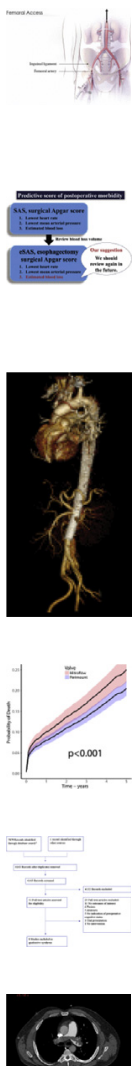

CURRENT READINGS: Single vs Bilateral Interna Mammary Artery in Coronary Artery Bypass Grafting. Sary F. Aranki. Semin Thoracic Surg 2018: Volume 30, Issue 4

ORIGINAL SUBMISSION: Open Repair of Thoracoabdominal Aortic Aneurysm: Step-by-Step. Joseph S. Coselli. Oper Tech Thorac Cardiovasc Surg. Spring 2018

ORIGINAL SUBMISSION: TEVAR for Acute Complicated Type B Aortic Dissection. Edward P. Chen. Oper Tech Thorac Cardiovasc Surg. Spring 2018

ORIGINAL SUBMISSION: Esophagectomy surgical Apgar score may not be associated with postoperative morbidity. Yoshitaka Aoki. Semin Thoracic Surg 2018: In press

ORIGINAL SUBMISSION: True Lumen Stabilization to Overcome Malperfusion in Acute Type I Aortic Dissection. Konstantinos Tsagakis. Semin Thoracic Surg 2018: In press

ORIGINAL SUBMISSION: Comparison of survival after aortic valve replacement with Mitroflow or Perimount prostheses. Kristian Aasbjerg. Semin Thoracic Surg 2018: In press

EXPERT REVIEW: Postoperative Outcomes in SAVR/ TAVR Patients with Cognitive Impairment: A Systematic Review. Richard D. Urman. Semin Thoracic Surg 2018: In press

CURRENT READINGS: Heparin-Induced

Thrombocytopenia and Cardiac Surgery. Aditya M. Sharma. Semin Thoracic Surg 2018: In press

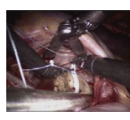

SURGICAL TECHNIQUE: Five Maneuvers to Facilitate Faster Robotic Mitral Valve Repair. Marc Gillinov. Semin Thoracic Surg 2018: In press

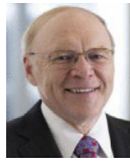

AORTIC SYMPOSIUM: Root Reimplantation With Leaflet Repair. Lars G. Svensson. Semin Thoracic Surg 2018: In press

Editorial Commentary: Words of Wisdom on Valvesparing Aortic Root Reimplantation when Leaflet Repair is Necessary. Leonard N. Girardi. Semin Thoracic Surg 2018: In press

CASE REPORT: Minimizing atheromatous emboli during arch surgery with a sequential debranching procedure. François Dagenais. Semin Thoracic Surg 2018: In press

ORIGINAL SUBMISSION: Incidence of Aortitis in Surgical Specimens of the Ascending Aorta Clinical Implications at Follow-Up. Uberto Bortolotti. Semin Thoracic Surg 2018: In press

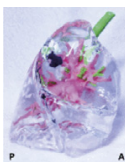

BRIEF RESEARCH REPORT: Personalized 3D-Printed Model for Informed Consent for Stage I Lung Cancer: A Randomized Pilot Trial. Young Tae Kim. Semin Thoracic Surg 2018: In press

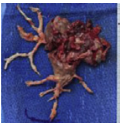

CASE REPORT: Independent Lung Ventilation for the Management of Unilateral Reperfusion Pulmonary Edema After Pulmonary Thrombendarterectomy: A Case Report. Maria D. Fritock. Semin Thoracic Surg 2018: In press

ORIGINAL SUBMISSION: Effect of Perioperative Neuromuscular Electrical Stimulation in Patients Undergoing Cardiovascular Surgery: A Pilot Randomized Controlled Trial. Sumio Yamada. Semin Thoracic Surg 2018: In press 


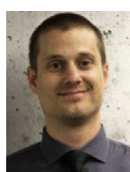

Editorial Commentary: Perioperative neuromuscular electrical stimulation: for the vulnerable cardiac surgery patient? Or is there more bang for your buck with exercise training? Dustin Kehler. Semin Thoracic Surg 2018: In press

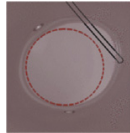

ORIGINAL SUBMISSION: Sutureless Valve Replacement Through a Right Anterior Minithoracotomy in Elderly Patients With Stenotic Bicuspid Aortic Valve. Mustafa Serkan Durdu. Semin Thoracic Surg 2018: In press

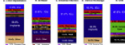
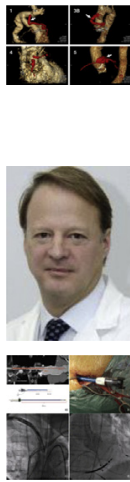

ORIGINAL SUBMISSION: Better With Time: An Economic Assessment of Long-Term Mechanical Circulatory Support in a Population Surviving at Least 1 Year with a Left Ventricular Assist Device. Pavan Atluri. Semin Thoracic Surg 2018: In press

ORIGINALSUBMISSION: Use Side Branch of the Aortic Graft to Facilitate Coronary Reconstruction During Complex Aortic Surgery. Yi-Tso Cheng. Semin Thoracic Surg 2018: In press

Editorial Commentary: What if "Cabrol" Lost Half of Its Mustache? Francois Dagenais. Semin Thoracic Surg 2018: In press

ORIGINAL SUBMISSION: Axillary Transcatheter Aortic Valve Replacement in Patients With Peripheral Vascular Disease. Ilir Hysi. Semin Thoracic Surg 2018: In press

Editorial Commentary: Alternative TAVR Access: Is It Time to Alter Your Alternative Access Strategy? Kendra J. Grubb. Semin Thoracic Surg 2018: In press

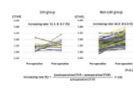

ORIGINAL SUBMISSION: Functional Evaluation of the Myocardial Ischemia After Coronary Artery Bypas Surgery Using Coronary Flow Velocity Reserve in Left Ventricular Hypertrophy. Kentaro Honda. Semin Thoracic Surg 2018: In press

ORIGINAL SUBMISSION: The Clinical Significance of Cerebral Microbleeds in Infective Endocarditis Patients. Ryosuke Murai. Semin Thoracic Surg 2018: In press

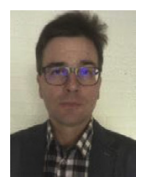

Editorial Commentary: The truth perturbs in the seemingly negligible; brain magnetic resonance imaging and endocarditis. Ari A. Mennander. Semin Thoracic Surg 2018: In press

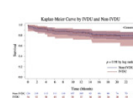

ORIGINAL SUBMISSION: Recidivism Is the Leading Cause of Death Among Intravenous Drug Users Who Underwent Cardiac Surgery for Infective Endocarditis. Arnar Geirsson. Semin Thoracic Surg 2018: In press

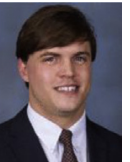

Editorial Commentary: Stop Draggin' My Heart Around Recidivism, Intravenous Drug Use, and Endocarditis. Dale Deas. Semin Thoracic Surg 2018: In press

STATE OF THE ART: Surgery for Tumors of the Heart. Bobby Yanagawa. Semin Thoracic Surg 2018:

Volume 30, Issue 4

ORIGINAL SUBMISSION: The Prevalence an Distribution of Occlusive Lesions of the Cerebral Arteries in Patients Undergoing Coronary Artery Bypass Graft Surgery: Tomohiro Tsunekawa. Semin Thoracic Surg 2018: Volume 30, Issue 4

\section{Coronary}

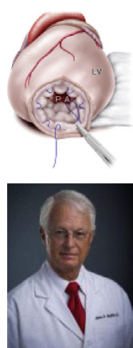

ORIGINAL SUBMISSION: "Frozen Apex Repair of a Dilated Cardiomyopathy. Masashi Komeda. Semin Thoracic Surg 2018: Volume 30, Issue 4

Editorial Commentary: The Frozen Apex: A Useful Addition to the Surgeons Armamentarium? James Kirklin. Semin Thoracic Surg 2018: Volume 30, Issue 4
ORIGINAL SUBMISSION: Remote Ischemic Preconditioning in High Risk Cardiovascular Surgery Patients: a Randomized-Controlled Trial. Nicole S. Coverdale. Semin Thoracic Surg 2018: 26-33

Editorial Commentary: Remote Ischemic Preconditioning: a Complex Question with an Even More Complex Answer. Sarah A. Schubert. Semin Thoracic Surg 2018: 34-35 


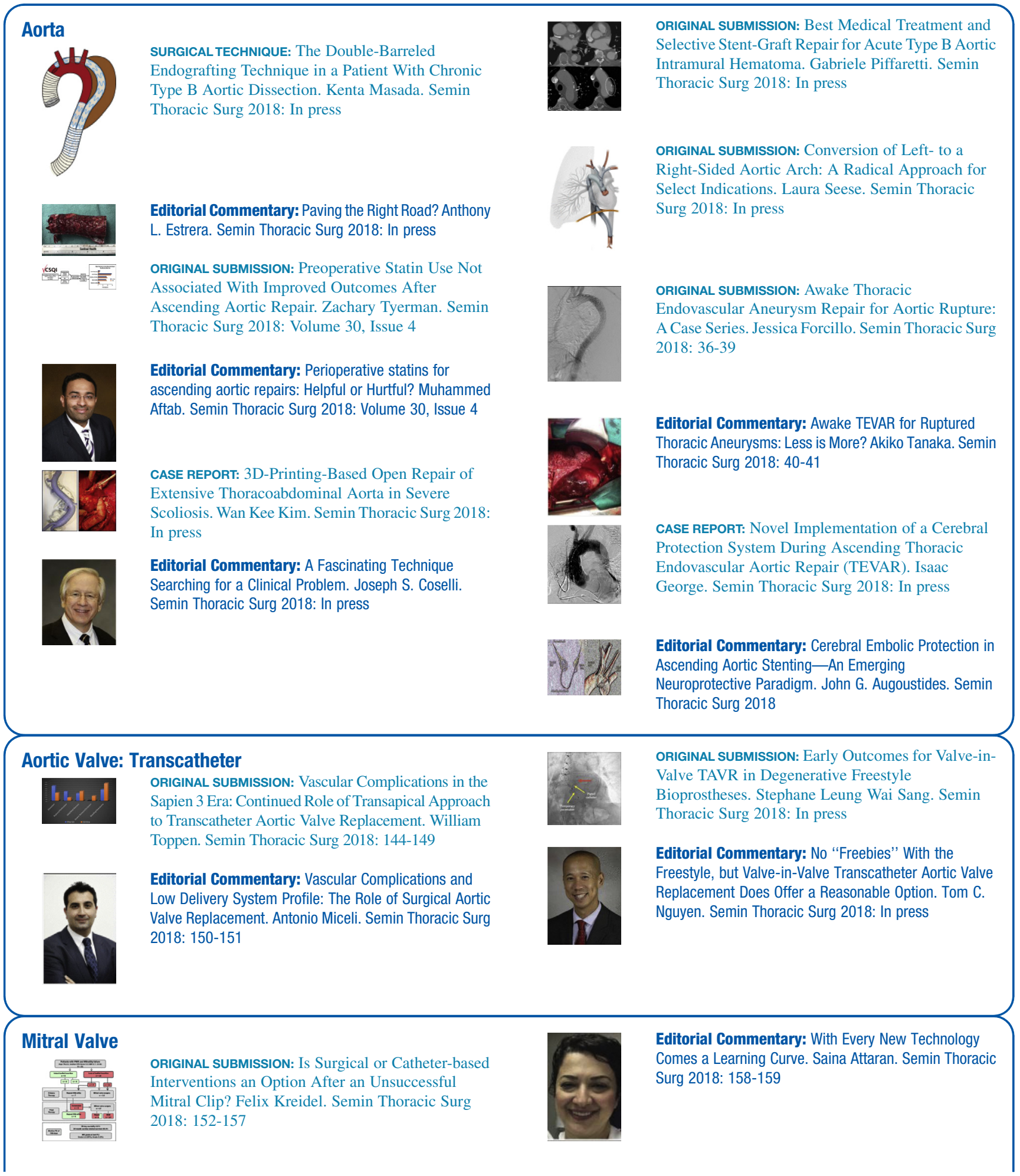




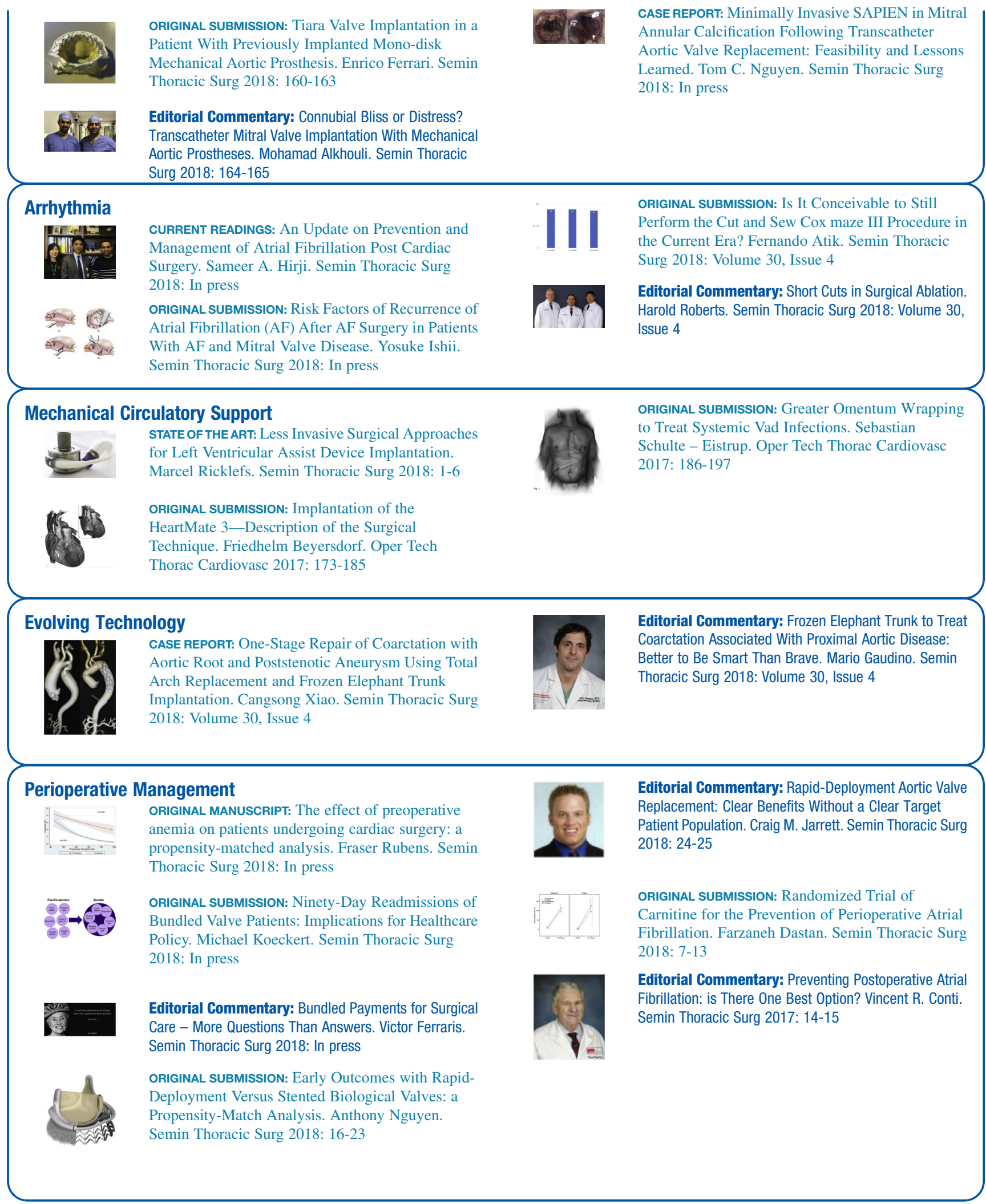




CURRENT READINGs: Surgical Approaches to
Hypertrophic Obstructive Cardiomyopathy. Zachary
Solomon. Semin Thoracic Surg 2018: 125-128

\section{CONGENITAL}

New

ORIGINAL SUBMISSION: Heart Transplantation in Situs Inversus Maintaining Dextrocardia. Katsuhide Maeda. Oper Tech Thorac Cardiovasc Surg. Spring 2018

ORIGINAL SUBMISSION: Repair of Intramural Coronary Artery in Anomalous Aortic Origin of a Coronary Artery. Yasuhiro Kotani. Oper Tech Thorac Cardiovasc Surg. Spring 2018

ORIGINAL SUBMISSION: Early Outcomes of Cardiac Surgery in Patients with Noonan Syndrome. Hartzell V. Schaff. Semin Thoracic Surg 2018: In press

SURGICALTECHNIQUE: Resection of Kommerell Diverticulum and Reimplantation of Aberrant Left Subclavian Artery in Right Aortic Arch Vascular Ring. Elham Bidar. Semin Thoracic Surg 2018: In press

\section{ORIGINAL SUBMISSION: Optimal Pulmonary Valve}

Annulus Diameter for Annulus Preservation in Tetralogy of Fallot May Be Far Smaller Than Normal Annulus Size. Tae-Jin Yun. Semin Thoracic Surg 2018: In press
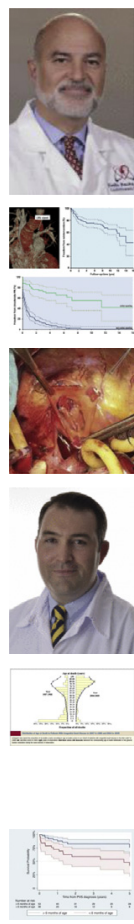

Editorial Commentary: Increased Reinterventions After Valve-Sparing Tetralogy of Fallot Repair: Is It the Price to Pay? Emile A. Bacha. Semin Thoracic Surg 2018: In press

ORIGINAL SUBMISSION: Tetralogy of Fallot in the Current Era. De Groot. Semin Thoracic Surg 2018: In press

EXPERT REVIEW. Aortic Valve Interventions in Pediatric Patients. Ismail Bouhout. Semin Thoracic Surg 2018: In press

Editorial Commentary: Aortic Valve Interventions in Children: Still Only Scratching the Surface. Patrick 0. Myers. Semin Thoracic Surg 2018: In press

CURRENT READINGS: Seminars in Thoracic and Cardiovascular Surgery-Current Readings: Adult Congenital Heart Surgery. Stephanie Fuller, Semin Thoracic Surg 2018: In press

ORIGINAL SUBMISSION: Pulmonary Vein Stenosis: Outcomes in Children with Congenital Heart Disease and Prematurity. Michael DiLOrenzo. Semin Thoracic Surg 2018: In press 


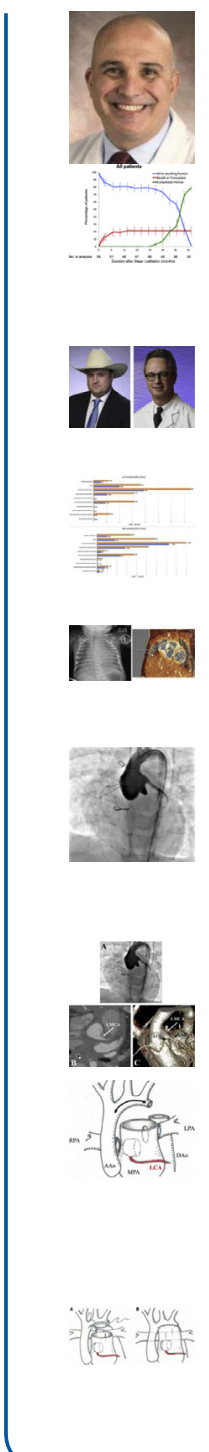

Editorial Commentary: Cracking the Mystery of Pulmonary Vein Stenosis. Bahaaldin Alsoufi. Semin Thoracic Surg 2018: In press

ORIGINAL SUBMISSION: Simultaneous Systemic to Pulmonary Shunt and Pulmonary Artery Banding is a Viable Option for Neonatal Palliation of Single Ventricle Physiology. S. Ram Kumar. Semin Thoracic Surg 2018: In press

\section{Editorial Commentary: If You Cannot Trust a} Bulboventricular Foramen, Whom Can You Trust? Robert D.B. Jaquiss. Semin Thoracic Surg 2018: In press

ORIGINAL SUBMISSION: The Prevalence and Impact of Congenital Diaphragmatic Hernia among Patients Undergoing Surgery for Congenital Heart Disease. Charles Fraser. Semin Thoracic Surg 2018: In press

Editorial Commentary: A Concise Message on CDH: Rare-Yes; Risky—Probably. Scott M. Bradley. Semin Thoracic Surg 2018: In press

SURGICAL TECHNIQUE: Three-patch aortic root reconstruction with extended left main coronary artery patch augmentation in neonates and infants. Nicholas Andersen. Semin Thoracic Surg 2018: In press

Editorial Commentary: Old Dog, New Tricks. Christopher Mascio. Semin Thoracic Surg 2018: In press

SURGICALTECHNIQUE: A Novel Aortic

Reconstruction for Anomalous Left Coronary Arising From the Right Pulmonary Artery in Hypoplastic Left Heart Syndrome: Successful Surgical Treatment. Takeshi Konuma. Semin Thoracic Surg 2018: Volume 30, Issue 4

Editorial Commentary: Neoaortic Root Incorporation of Anomalous Left coronary Artery from Pulmonary Artery in Hypoplastic Left Heart Syndrome: An Alternative Technique. Meena Nathan. Semin Thoracic Surg 2018: Volume 30 , Issue 4

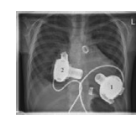

CASE REPORT: Intracorporeal Biventricular Assist Device Therapy in an 8-Year-Old Child. Antonia Schulz: Semin Thoracic Surg 2018: In press
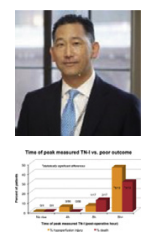

Editorial Commentary: Feasibility of biventricular intracorporeal ventricular assist in a pediatric patient. Paul Chai. Semin Thoracic Surg 2018: In press

ORIGINAL MANUSCRIPT: Postoperative Serum Troponin Trends in Infants Undergoing Cardiac Surgery. Jennifer Su. Semin Thoracic Surg 2018: In press

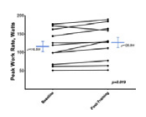

ORIGINAL SUBMISSION: A Pilot Study of Inspiratory Muscle Training to Improve Exercise Capacity in Patients with Fontan Physiology. Fred Wu. Semin Thoracic Surg 2018: Volume 30, Issue 4

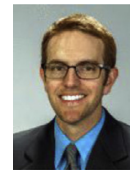

Editorial Commentary: Cardiopulmonary Rehabilitation Therapy in Congenital Heart Disease: What Will it Take to Gain Traction? Samuel Wittekind. Semin Thoracic Surg 2018: Volume 30, Issue 4

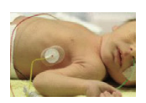

ORIGINAL SUBMISSION: Risk Factors for Gastrostomy Tube Placement in Single Ventricle Patients Following The Norwood Procedure. Kurt Piggott. Semin Thoracic Surg 2018: Volume 30, Issue 4

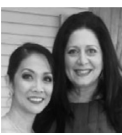

Editorial Commentary: Gastrostomy Tubes in PostNorwood Patients: Why, When and How are as Important as the Who. Nancy Ghanayem. Semin Thoracic Surg 2018: Volume 30, Issue 4

CASE REPORT: How Could Aortic Atresia With Interrupted Aortic Arch Survive? About a Neonatal Repair on Two Ventricles. Francois Lacour-Gayet. Semin Thoracic Surg 2018: In press

\section{Transposition of the Great Arteries}

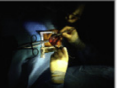

ORIGINAL SUBMISSION: Outcomes of the Arterial Switch Operation in $\leq 2.5-\mathrm{kg}$ Neonates. Michael Salna. Semin Thoracic Surg 2018: In press

\section{Congenital Trachea}

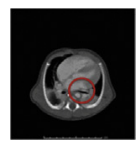

ORIGINAL SUBMISSION: Descending Aortopexy and

Posterior Tracheopexy for Severe Tracheomalacia

and Left Mainstem Bronchomalacia. Hester F.

Shieh. Semin Thoracic Surg 2018: In press 


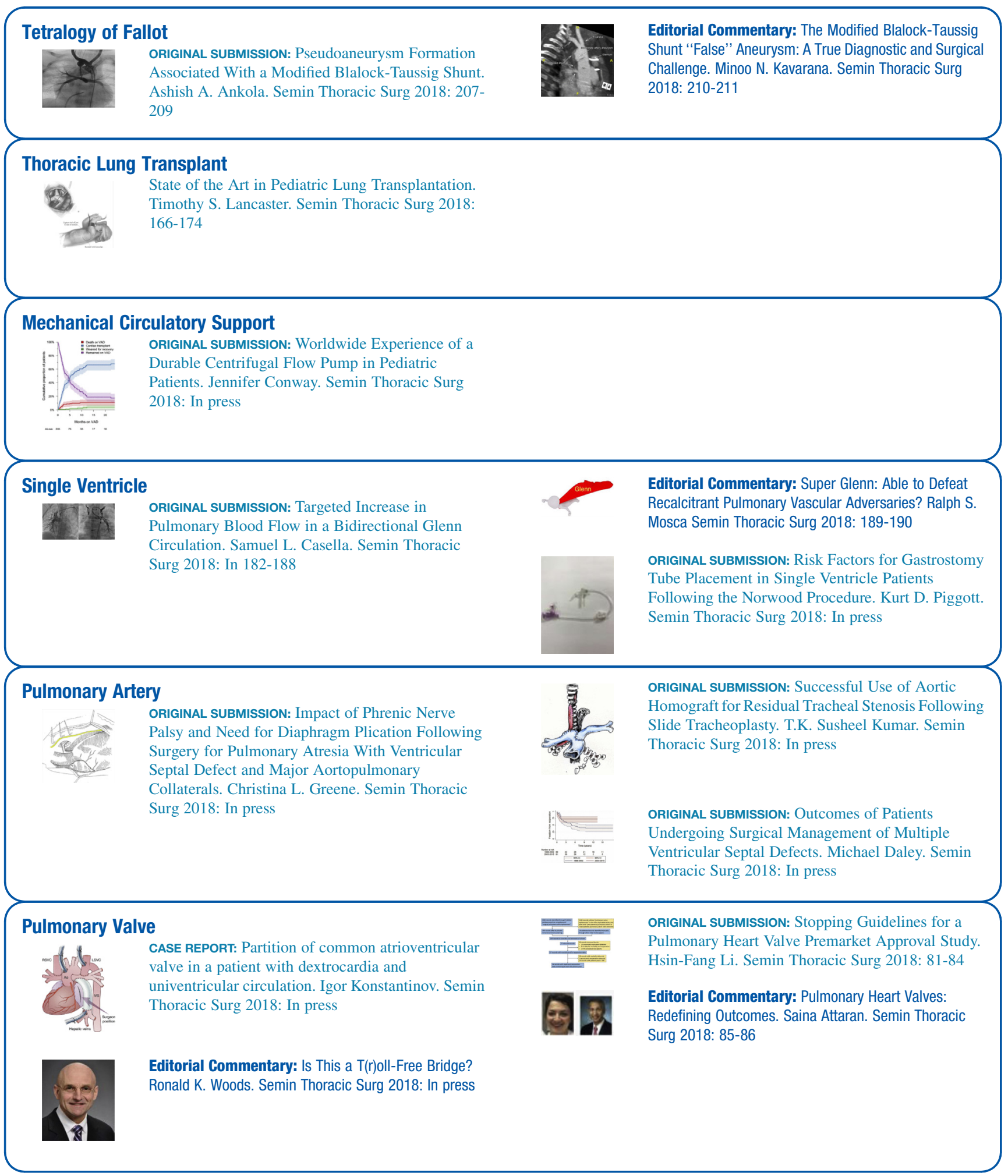




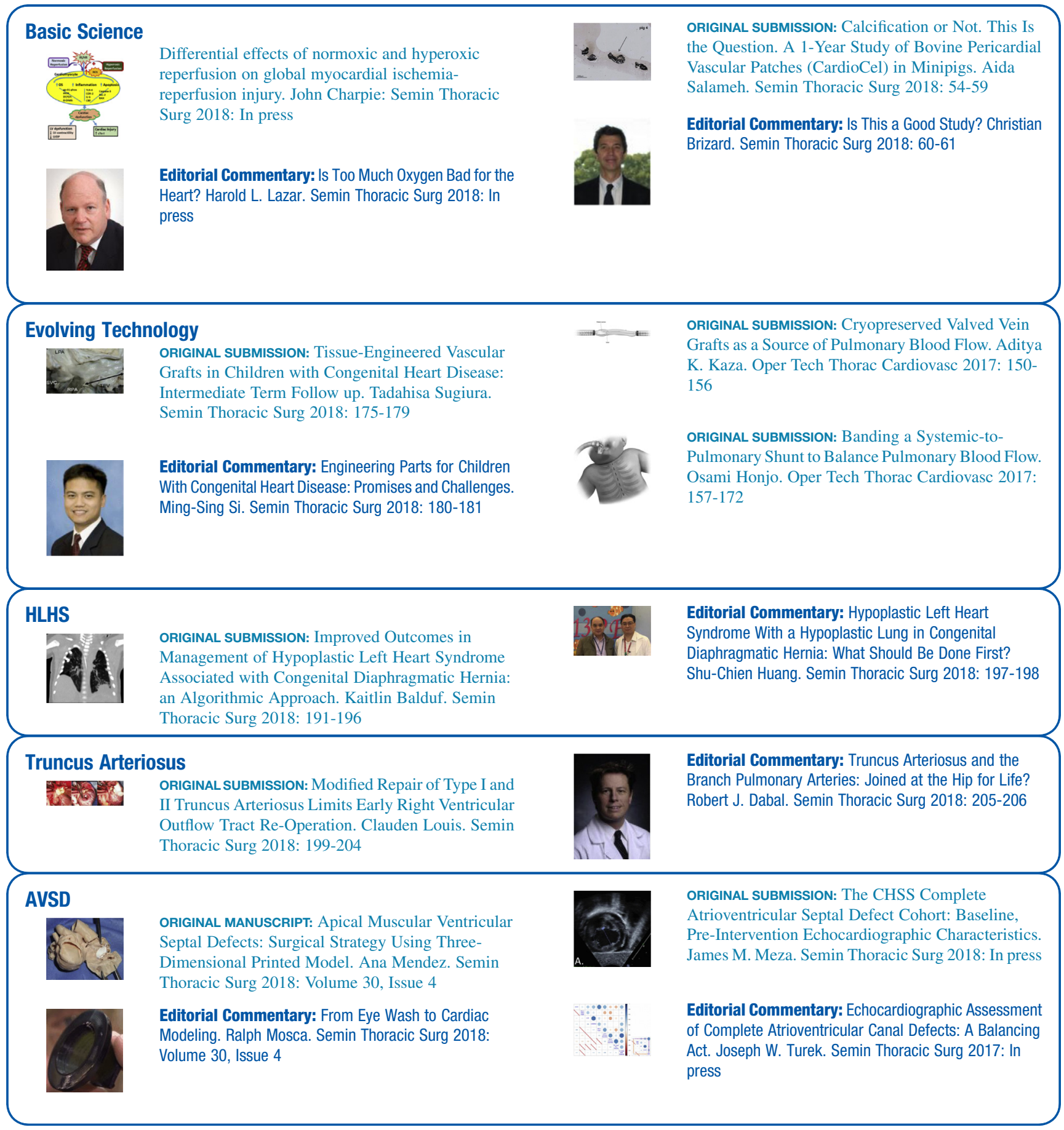




ORIGINAL SUBMISsIon: The Right Axillary Incision: a
Potential New Standard of Care for Selected
Congenital Heart Surgery. Timothy Lee. Semin
Thoracic Surg 2017: In press

